OPEN ACCESS

Edited by:

Priscilla Claeys,

Coventry University, United Kingdom

Reviewed by:

Eduardo García-Frapolli, Universidad Nacional Autónoma de

México, Mexico

Griet Steel,

Utrecht University, Netherlands

*Correspondence: Verónica Vázquez-García vvazquez@colpos.mx

Specialty section:

This article was submitted to Social Movements, Institutions and Governance,

a section of the journa Frontiers in Sustainable Food Systems

Received: 22 January 2021 Accepted: 26 May 2021

Published: 29 June 2021

Citation:

Vázquez-García $V$ and Sosa-Capistrán DM (2021) Examining the Gender Dynamics of Green Grabbing and Ejido Privatization in

Zacatecas, Mexico

Front. Sustain. Food Syst. 5:657413 doi: 10.3389/fsufs. 2021.657413

\section{Examining the Gender Dynamics of Green Grabbing and Ejido Privatization in Zacatecas, Mexico}

\author{
Verónica Vázquez-García ${ }^{1 *}$ and Dulce María Sosa-Capistrán ${ }^{2}$ \\ ${ }^{1}$ Department of Rural Development, Colegio de Postgraduados, Texcoco, Mexico, ${ }^{2}$ Universidad Autónoma de San Luís \\ Potosí, Latin American Program on Territory, Society and Culture, San Luís Potosí, Mexico
}

The ejido is the most important form of collectively owned property in Mexico; approximately half of the country's territory belongs to ejidatarios of whom women make up roughly $20 \%$. Recent legal reforms aimed at privatizing the ejido are forcing ejidatarios/as to sell or rent their lands to corporations seeking to invest in oil, mining, and energy production. This paper examines the gender impacts of land privatization for renewable energy generation in two ejidos of Zacatecas, Mexico: El Orito and Benito Juárez. The first agreed to rent their lands to a private company while the other did not. Results show that land rentals benefitted a handful of ejidatarios, while the people affected the most include male stone miners, ejidatarias who were excluded from decision-making, and women who obtain food and fuel from ejido common lands. Benito Juárez served as a good point of comparison because its common lands were not privatized, and people continue to use them in traditional ways. However, people in Benito Juárez also hold different bundles of rights to common lands based on gender, economic status and age. The paper calls for a gender and intersectional approach to continue examining the differentiated impacts of ejido privatization in Mexico.

Keywords: gender, land privatization, common lands, intersectionality, ejido

\section{INTRODUCTION}

The ejido is the most important form of collective land ownership in Mexico. It is a product of the revolution of 1910 which led to the expropriation of rich landowners in order to distribute land among landless peasants. According to the Agrarian Law contained in the Constitution of 1917, each household should receive a plot for cultivation and have access to common lands not suitable for agriculture or human settlement that are part of an ejido (Procuraduría Agraria, 2009). Typically, ejido common lands are used for water conservation, food and fuel collection, religious celebrations and community fiestas. Heads of households (assumed male) are called ejidatarios, and ejidos are governed by an assembly of ejidatarios. One hundred years later, ejidos continue to be the most important form of collective property in Mexico, with approximately half of the total surface of the country (106 million out of 200 million hectares) belonging to 5,700,000 ejidatarios (GRAIN, 2014). Women were allowed to become ejidatarias in 1971, and presently only $20 \%$ of ejidatarios are female (Vázquez-García, 2016). Typically, they are elderly (61 years old on average) widows expected to transfer their ejido rights to their sons when they reach adulthood. In fact, four out of 10 ejidatarias transfer their land rights to one of their adult sons while still living (Costa Leonardo and Velasco Ocampo, 2012). 
In spite of their importance for Mexico's history and rural development, ejidos face numerous threats. Among the most important ones are the constitutional changes of 1992 that enabled the privatization of ejido lands, and the energy reform of 2013 that declared oil, mining and electricity as sectors of national priority. Ejidatarios were persuaded to accept the intervention of the Program for the Certification of Ejido Rights (PROCEDE) in their ejidos in order to grant land titles to each ejidatario, and to sell or rent their property to private corporations. The overwhelming majority (92.24\%) of ejidos have been subdivided into individual plots by PROCEDE (Andrade Sáenz, 2009), and the Movement for Food Sovereignty and Defense of Land, Water, Natural Resources, and Territory has suggested that the energy reform represents a threat to around $60 \%$ of them (Hernández Navarro, 2016).

Research on the gender impacts of these changes is starting to emerge. So far, we know that a handful of men, usually ejido authorities, are the only ones capable of negotiating with private corporations, thus contributing to ejidatarias' exclusion from decision-making (Gay-Antaki, 2016; García-Torres, 2018). If no other choice is available, the few ejidatarias existing in the country prefer to rent rather than to sell their ejido lands (Ruiz Meza, 2006, 2012; Zapata et al., 2006; Almeida, 2012a,b). More research is needed on the impact of these changes not only on ejidatarias, but on men and women at large, both in terms of the economic benefits they may obtain from land rentals, and their changing access to ejido common lands.

This paper examines the impacts of ejido privatization for renewable energy production in Mexico. It focuses on La Bufa wind farm which began operations in 2016 in the northern state of Zacatecas. Data were obtained in two ejidos belonging to the municipality of Zacatecas: El Orito and Benito Juárez. The first rented their common lands to Mexico Power Group (MPG) to build the wind farm while the second did not.

Fieldwork was conducted in 2017 and 2018. In October and November 2017, 80 questionnaires were applied to women (40 in El Orito, 40 in Benito Juárez) in order to enquire into their perceptions of climate change and renewable energies; wind farm installation; and domestic use of energy. During the same period of time, two workshops were carried out in order to discuss preliminary results with women. Between July 2017 and May 2018, 22 in-depth interviews were conducted with government officials, NGO personnel, MPG workers, and ejidatarios of both sexes. Finally, three meetings with government officials, NGO's and members of the ejidos were made in order to influence energy policy from a gender perspective. The first took place in April 2018, the second in June of the same year, and the last in July of the same year. ${ }^{1}$ All names included in this paper are fictional in order to maintain the confidentiality requested by most research participants.

The original focus of research was women's relationship with renewable energies. The two ejidos were selected because they were part of a solar energy program, and both were involved

\footnotetext{
${ }^{1}$ See Vázquez-García and Sosa-Capistrán (2020) and Buechler et al. (2020) for an analysis of women's adoption of renewable energies (solar boilers for domestic use) in Zacatecas.
}

in La Bufa land negotiation deals. As fieldwork advanced, it became clear that common lands were essential for such deals because wind farms necessarily require large extensions of land to operate. Thus, additional information was gathered on ejido characteristics; how the company approached ejidatarios; and the contract negotiation process. Supplementary research methods include the revision of the official files of El Orito and Benito Juárez at the Registro Agrario Nacional in order to identify the amount and sex of ejidatarios; the extension of the two ejidos; and some key moments in the history of both of them.

The paper takes a comparative approach to examine the gender dynamics of common land rentals in El Orito compared to Benito Juárez. It is subdivided as follows. The next section discusses the concept of green grabbing from a gender and intersectional approach. Section three presents relevant information on the windfarm and the two ejidos. Research results are discussed in sections four and five, mainly the gender dynamics of land rentals in El Orito, and patterns of land use by gender, economic status and age in both El Orito and Benito Juárez. Section six presents some concluding remarks and examines their implications for the literature on green grabbing.

\section{THEORETICAL APPROACH: GREEN GRABBING FROM A GENDER AND INTERSECTIONAL APPROACH}

Land tenure institutions create different groups of people with distinct bundles of rights involving access, use, management, exclusion, and alienation (Schlager and Ostrom, 1992). Access refers to the possibility of entering common lands; use has to do with the additional possibility to extract resources from them. The last three (management, exclusion, and alienation) involve decision-making bodies that regulate land use patterns and transformation; who can intervene in them; and the possibility to sell or lease the land (Larson et al., 2010). Bina Agarwal's research in India $(1994 ; 2003)$ has argued that having a full bundle of rights contributes to rural women's bargaining power within and outside the household. Studies conducted in various parts of Latin America reports similar results. Women who own land are more likely to choose their life partners, end domestic abuse, get support from their children in old age and participate in household decision-making regarding agricultural production and use of income (Deere and León, 2005). Unfortunately, women's bundle of rights is usually smaller than men's. Women tend to have operational (access and use) as opposed to decisionmaking rights (management, exclusion, and alienation) (Gray and Kevane, 1999). Operational rights may contribute to the food, water, and energy security of women's households, but not necessarily to the improvement of their gender status (Brown, 2004; Behrman et al., 2012).

Women's limited bundle of rights results from their status as incomplete beings whose access to resources (and chances for survival) depends on their ties with male kin. For example, in Cameroon, women lose access and use rights to common lands if they divorce and then remarry. In Nigeria, women may extract forage, snails and fungi from common areas, but they 
need permission from male relatives to harvest trees (Hoang Yen et al., 2012). In Uganda, women can get firewood from trees previously harvested by men, but they cannot climb them because it may bring bad luck (Banana et al., 2012; Mukasa et al., 2012). In Veracruz, Mexico, natural resources are protected by naughty chaneques (similar to Nordic goblins) that may put women's good reputation at risk if they go to common lands unaccompanied by men (Vázquez-García, 2007). In Oaxaca, also in Mexico, resource extraction from common lands is justifiable merely for subsistence purposes, which in the case of women only applies to widows who must maintain young children. In other words, married women cannot use resources from common lands because their husbands are expected to provide for them (Vázquez-García and Ortega Ortega, 2017).

Women's incomplete status places them in a vulnerable position vis-à-vis land privatization processes such as the energy reform of Mexico. Wind energy is one of the most promising ways to deal with climate change, although it has the inconvenience that it may involve land grabs. (Daley, 2011, p. 2) defines land grabbing as the set of mechanisms through which poorer landholders sell or lease their land to wealthier people, "enabling for the concentration of land ownership and rights into the hands of those few with enough resources to invest in land development on a larger scale." Green grabs specifically refer to land deals targeted to fight climate change, for example, REDD+ (Reducing Emissions from Deforestation and Forest Degradation), biofuel crops and wind farms. All three initiatives seek to reduce carbon emissions in the Global South to the benefit of the Global North, where most polluting countries are found, and they operate with the complicity of state agencies that portray green grabs as positive for people and for the environment (Tejada and Rist, 2019; Trench and Amico, 2019).

Green grabs affect rural people in different ways, depending on their gender, economic status and age. Some local, privileged groups may benefit from them, as they actively seek to improve land revenues by negotiating directly with investors (Borras and Franco, 2013). In terms of age, the voices of young people regarding land deals remain unheard (Scoones et al., 2013). Accordingly, research has shown that women reap few benefits from green grabs due to their lack of access to information on the project; their unequal representation in decision-making bodies; and their reduced bargain power vis-à-vis governmental authorities and private investors (Daley, 2011; Daley and Pallas, 2014; Fonjong et al., 2016). Land payments are mostly directed to men, while the increasing difficulties to obtain water, food and fuel in common areas affect women the most (White and White, 2011; Behrman et al., 2012; Ossome, 2014; Fonjong et al., 2016). More research is needed on the differences between various groups of women and men to further determine the benefits that they may receive or the affectations they may suffer from land deals depending on the intersection of gender, economic status and age.

This paper takes a gender and intersectional approach to examine the impacts of green grabbing in Zacatecas, Mexico. The concept of intersectionality proposed by black feminist (Crenshaw, 1989, p. 149) suggests that women's experiences with discrimination do not result from a single factor, but rather, from the combination of many. "Discrimination, like traffic through an intersection, may flow in one direction, and it may flow in another. If an accident happens in an intersection, it can be caused by cars traveling from any number of directions and, sometimes, from all of them. Similarly, if a Black woman is harmed because she is in the intersection, her injury could result from sex discrimination or race discrimination." From this perspective, women experience gender discrimination as a combination of patriarchal violence, cultural imperialism, economic exploitation, racialization, and age exclusion (Mollett and Faria, 2013; Hernández Artigas, 2018). Resistance to these distinct forms of oppression may take multiple shapes: demands for resource redistribution, social recognition or participation in decision-making (Fraser, 2008). A gender and intersectional approach seeks to expose the different ways in which women experience discrimination and their responses to it (Sales Gelabert, 2017). Each context determines the factors that shape women's experiences and struggles. In El Orito and Benito Juárez, racial or ethnic differences are not relevant, since all women consider themselves mestizas, and none of them belongs to an indigenous group. In fact, only $0.33 \%$ of the population of Zacatecas are indigenous, compared to other states of Mexico such as Oaxaca where the percentage is $31.18 \%$ (Instituto Nacional de Estadistica Geografía e Informatica, 2020). The distinguishing factors creating differences among women, and also among men, are gender, economic status and age. All three dimensions shape their relationship with land and people's chances to access, use or manage common lands, as will be seen shortly.

\section{RESEARCH SITE}

The state of Zacatecas has two wind farms currently in operation: Vientos del Altiplano and La Bufa. The first is located in the municipalities of Mazapil and Villa de Cos, while the second is situated in the municipalities of Zacatecas, Guadalupe, Genaro Codina, and Villanueva. The La Bufa wind farm generates $180 \mathrm{MW}$ with 90 mills capable of supplying energy to 209,000 households (Gobierno de Zacatecas, 2017). However, Volkswagen car plants located in Guanajuato and Puebla profit from the energy generated at La Bufa windfarm, in accordance with the Energy Transition Law enacted in 2015 that privileges the generation of clean energy by and for private companies. Nationwide, most wind energy benefits private companies such as Bimbo, Coca-Cola, Wallmart, and Volkswagen (Avilés Hernández, 2013; Juárez-Hernández and León, 2014). In practical terms, this means that the Mexican state has become instrumental to multinational companies profiting from the very justifiable need to reduce carbon emissions and fight climate change. The capital city of Zacatecas has 42,394 households (Instituto Nacional de Estadistica Geografía e Informatica, 2020). A windfarm capable of providing with clean energy to four times that amount is serving private interests rather than those of the population.

La Bufa wind farm was built by Mexico Power Group (MPG). Originally constituted in 1979, MPG has developed 


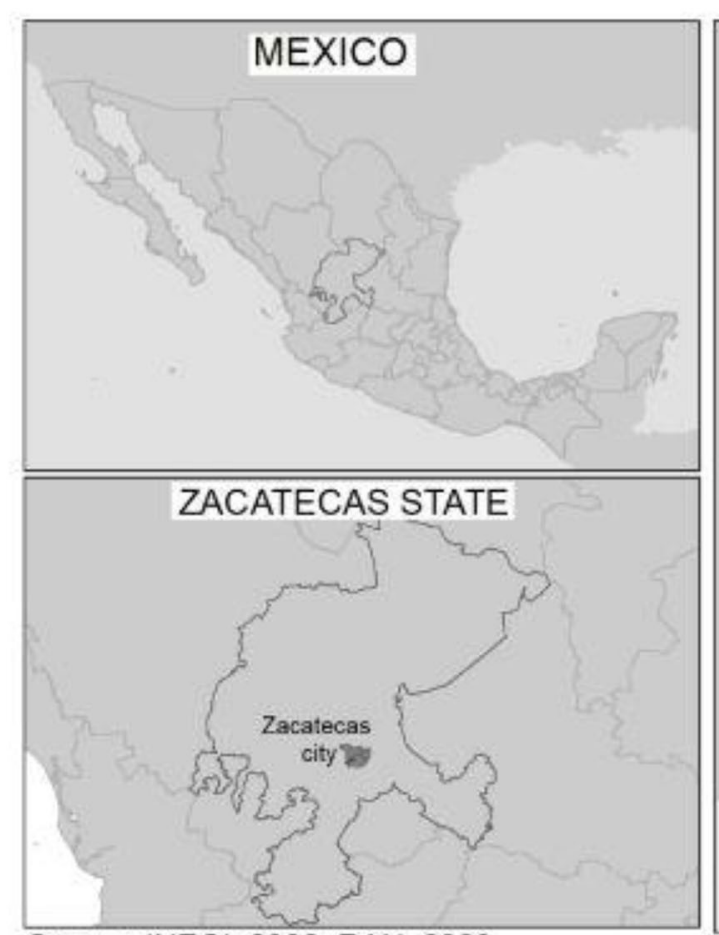

Source: INEGI, 2020; RAN, 2020.

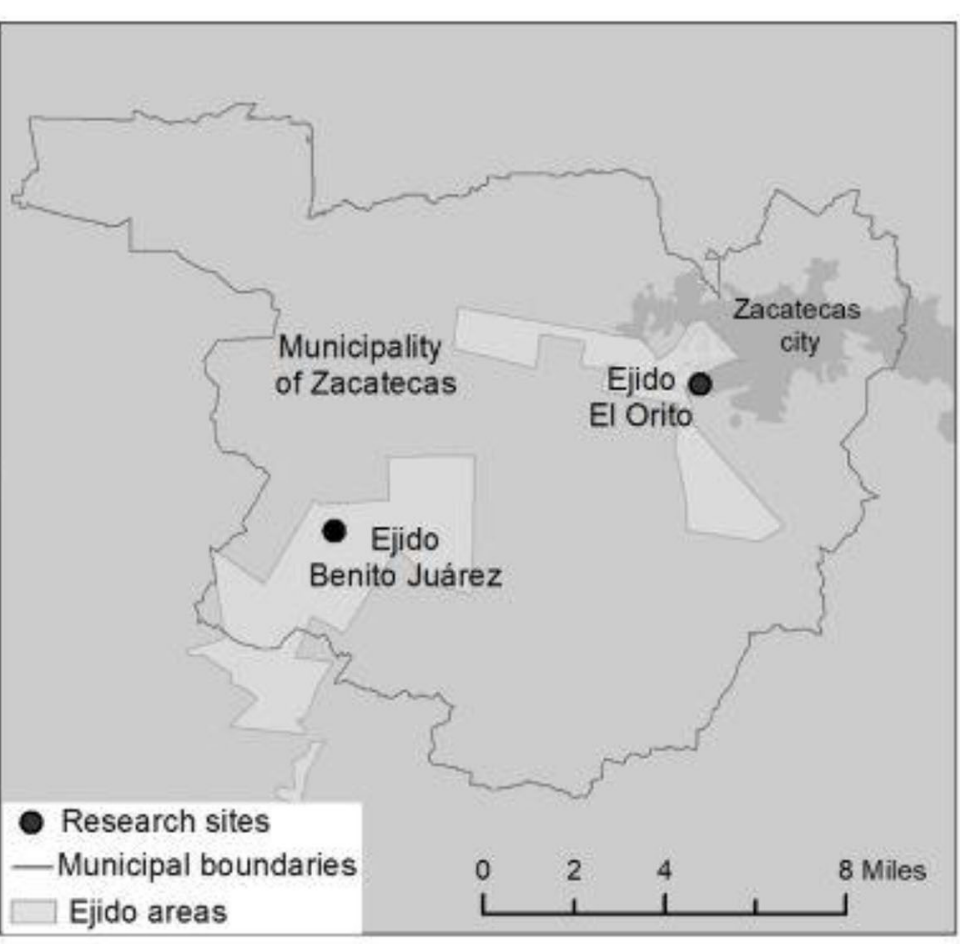

Ejido areas

FIGURE 1 | Research sites.

similar projects in nine states of Mexico, "covering practically all areas with significant wind in the country" (México Power Group, 2014). Although Mexican, MPG depends on the Spanish corporation Gamesa for the development and delivery of all technology involved in building and operating wind farms (Martínez Mendoza et al., 2018). La Bufa wind farm started operations in 2016, but MPG personnel arrived to the area in 2009 to obtain consent from ejidatarios to rent their lands. State officials working for the Agrarian Attorney's Office played a pivotal role in the promotion of MPG interests, as will be seen shortly.

\section{The Two Ejidos}

The state of Zacatecas has 755 ejidos covering half $(37,520$ $\mathrm{km}^{2}$ ) of the state's territory. These ejidos belong to $\sim 140,000$ ejidatarios, and agriculture is practiced in most of them (Centro de Estudios para el Desarrollo Rural Sustentable y la Soberanía Alimentaria, 2015). The most important crops grown in the state are bean, maize, oatmeal, fruits (grape and guayaba), and vegetables (lettuce, green tomato, hot pepper, and onion) (Secretaría de Agricultura y Desarrollo Rural, 2018). In addition, the majority of ejidos in Zacatecas (98\%) practice animal husbandry, mostly bovine (Centro de Estudios para el Desarrollo Rural Sustentable y la Soberanía Alimentaria, 2015).

El Orito and Benito Juárez are part of the municipality of Zacatecas (Figure 1). El Orito is located very close to the city of Zacatecas, capital of the state, and it has some urban areas used for housing rather than agriculture. By contrast, Benito Juárez is located $40 \mathrm{~min}$ away by car, and preserves a much more rural landscape. El Orito's proximity to the city of Zacatecas explains its acceptance to rent their common lands as opposed to Benito Juárez due to constant urban growth and encroachment of ejido lands. Some parts of El Orito still have an agricultural orientation, but many residents make a living as drivers, bricklayers or mechanics (men) and domestic workers, street vendors or seamstresses (women). Affluent families own small businesses and/or are supported by children with University degrees. By contrast, people in Benito Juárez depend much more on agriculture for daily subsistence. Approximately half of the ejido's arable lands have irrigation and are used for commercial crops (mostly maize and beans). The annual income that each household may obtain from commercial crops is 20,500 pesos (around USD 1,000) per hectare; each ejidatario has $\sim 5$ hectares of irrigated lands. Food for household consumption is obtained from rainfed lands (maize and means) and common lands (animal grazing, hunting, and plant collection). Common lands are also important for landless, poor men who make a living as stone miners when agricultural work is not available.

Both ejidos were created shortly after the signing of the Constitution of 1917 and the implementation of the Agrarian Law. Table 1 shows that in 1995, PROCEDE granted individual titles of arable lands to 133 ejidatarios in El Orito, and acknowledged the existence of 1,464 hectares of common lands. 
TABLE 1 | Characteristics of El Orito and Benito Juárez.

\begin{tabular}{lcc}
\hline Characteristics & \multicolumn{2}{c}{ Ejido } \\
\cline { 2 - 3 } & El Orito & $\begin{array}{c}\text { Benito } \\
\text { Juárez }\end{array}$ \\
\hline Date of land distribution & 1925 & 1923 \\
Date of PROCEDE certification & 1995 & 2005 \\
Total number of hectares (according & 820 private & 2,187 private \\
to PROCEDE) & arable plots; & arable plots; \\
& 1,464 & 2,048 \\
& common & common \\
lands \\
Total number of ejidatarios & 133 & 214 \\
Total number of ejidatarias & 18 & 47 \\
Percentage of ejidatarias & $13 \%$ & $22 \%$ \\
\hline
\end{tabular}

Source: Registro Agrario Nacional (1998).

However, PROCEDE intervened a second time in 2006 in order to privatize these 1,464 hectares, granting 450 additional land titles to El Orito ejidatarios. The fragmentation of common lands was key for ejidatarios' acceptance to negotiate with MPG a few years later. Perhaps coincidentally, perhaps not, the newly created parcels were located in the area selected by the company to install the mills.

PROCEDE's intervention in Benito Juárez took place in 2005, around the same period of time when El Orito common lands were being privatized. PROCEDE granted individual titles of arable lands to 214 ejidatarios, and also acknowledged the existence of 2,048 hectares of common lands (Table 1). As opposed to El Orito, where the ejido assembly was weakened by PROCEDE's second intervention in 2006, the ejido assembly of Benito Juárez refused to privatize their common lands because they rely on them for subsistence. They also refused to begin negotiations with MPG for two main reasons: the excessive length of the lease contract (20 years minimum), and the legal obligation to change the use of land, from agricultural to industrial. Thus, MPG was forced to modify the original project in order to "go around" the common lands of Benito Juárez (Fabiola Sepúlveda, Visiting Judge, Agrarian Attorney's Office, Zacatecas).

\section{EJIDATARIAS' EXCLUSION FROM DECISION-MAKING AND LAND RENTALS IN EL ORITO}

According to the Agrarian Law, the decision-making process regarding land rentals for renewable energy or any other kind of private investment (mining, hydropower, biofuels) must take place at the ejidatarios' assembly (Procuraduría Agraria, 2009). However, MPG managed to obtain consent from less than half (60 of 133) of ejidatarios from El Orito on an individual basis, without having to deal with the assembly. All 60 ejidatarios own agricultural plots as well as common lands. Renting these latter represented additional income without putting their livelihoods at risk. Some of them also own small businesses. For example, the president of the ejido and main advocate for the MPG contract has a two-floor house and owns the largest and most famous hardware store in town.

Very few surveyed women knew about the wind farm's installation, with slight differences between the two ejidos $(10 \%$ in El Orito, 5\% in Benito Juárez). The majority of them (79\%) said that "they did not know" if wind energy is good or bad for the environment. Men who do not belong to the group of 60 ejidatarios in El Orito also had very vague information on the project. Wind farms are "like solar boilers. Now they will take electricity from the hills," said Rafael Pérez, a retired miner who also believes that the enterprise in charge of the wind farm is Canadian. According to José Gallardo, NGO trainer on renewable energies, the lack of access to information was intentional on the side of the government because they did not want people to know that the power would be taken to other states:

is for Volkswagen Puebla, and it is very frustrating to have the windmills here. Why do you think the government remained silent? They prefer not talk about the wind farm because people would notice... Sadly, the government has us with its foot on our heads, pinning us down on the floor. It is very sad (José Gallardo, NGO employee, Zacatecas).

Only $11 \%$ of the surveyed women identified benefits from the wind farm. Most of them are from El Orito, and most of them mentioned money as the most important benefit. In fact, income obtained from land rentals constitutes the most important benefit, if not the only one, that people can obtain from enterprises such as MPG (Torres Fragoso and Luna Espinoza, 2018). In El Orito, the 60 ejidatarios had to form a cooperative in order to receive their payments. The contract established $4 \%$ royalties in relation to energy sales (León, 2017). The amount is adequate when compared to wind farms in other countries where royalties fluctuate between 1 and $5 \%$ of net income. Elsewhere in Mexico, for example in the Isthmus of Tehuantepec, Oaxaca, wind farm contracts were signed a few decades earlier (1990's) and the amount received by ejidatarios is much lower- between 0.025 and $1.53 \%$. Only one wind farm in Oaxaca reports similar percentages to those of La Bufa (Energies Nouvelles, built in 2010, pays 3.38\%) (Comisión Nacional para el Diálogo con los Pueblos Indígenas de México, 2013). Clearly, the wind energy industry has become more efficient throughout the years, and corporations are in a better position to increase ejidatarios' royalty shares. However, payments are not received by all El Orito ejidatarios. From the very beginning, due to project design, $55 \%$ were excluded from the original deal, and even within the group of 60 ejidatarios there are differences in terms of the amounts to be received. Royalties are delivered as a lump payment that must be divided as follows: "those who have no infrastructure [windmills] in their terrains but are part of the whole area, will receive $40 \%$. Those of us who have infrastructure, I believe, will receive 60\%" (Mauricio López, ejidatario, El Orito, Zacatecas).

Ejidatarios belonging to the cooperative signed lease agreements for 20 years, with a chance of renewal. If an ejidatario 
(or an heir) refuses to do so 20 years from now, he or she has to sell the land to the enterprise in order to guarantee the continuity of the project. "We did not know the mess we got ourselves into. Maybe we did some things right, maybe we did some things wrong. Why? Because we did not know" (Mauricio López, ejidatario, El Orito, Zacatecas). By contrast, Fabiola Sepúlveda, Visiting Judge working for the Zacatecas branch of the Agrarian Attorney's Office, believes that ejidatarios were properly counseled, and that the contract was "fair and legal." According to her, ejidatarios refuse to understand the times we live in:

Ejidatarios want to continue with the same old scheme, and that is no longer possible. The agrarian reform has three stages. The first was [president] Lazaro Cardenas with the land distribution process; the second was [president Carlos] Salinas with PROCEDE. This is the third one. Ejidatarios must seek association, participation, investment, and make sure that land produces revenue not only from primary activities. This is the stage that ejidatarios refuse to understand, perhaps because they are getting old (Fabiola Sepúlveda, Visiting Judge, Agrarian Attorney's Office, Zacatecas).

Table 1 shows that 13\% of ejidatarios from El Orito are female. This is the reason why the cooperative includes only six (10\%) women. We had the opportunity to attend a meeting of the cooperative and meet three of them-all elderly widows who had inherited land rights from their deceased husbands. The other women were unable to attend the meeting, or were represented by their sons. This is how Fabiola Sepúlveda from the Agrarian Attorney's Office describes the six ejidatarias:

\footnotetext{
They are the heirs, the successors, because their husbands have already died. In El Orito, the assembly accepts their presence, but in other ejidos women do not attend assemblies because men do not allow it. In El Orito, even if women participate, they are used to asking their eldest son what to do. Plus, they always decide to bequeath their land to them (Fabiola Sepúlveda, Visiting Judge, Agrarian Attorney's Office, Zacatecas).
}

Sepulveda's description matches our experience at the cooperative meeting. We were unable to talk to the three ejidatarias because their sons were standing behind them, whispering in their ears when we asked a question. One ejidataria let it slip that she was satisfied with the deal with MPG: "any amount of royalties is all right" because "I am not greedy." She thought that the MPG contract was a gift from the government (which clearly facilitated the process) rather than a private investment. Situations like this have been reported time and time again: when dealing with corporations, a few men control the outcome, thus contributing to women's disempowerment (Gay-Antaki, 2016; García-Torres, 2018; Olivera, 2019). What is interesting in this case is that even the ejidatarias who enjoy the full bundle of rights granted by law were excluded from the process. In theory, ejidatarias have a voice and the right to vote in decision-making bodies. In practice, they are being replaced by their sons and receive no benefits from land deals, with the complicity of ejido authorities.

\section{LAND PRIVATIZATION AND CHANGING ACCESS TO COMMON LANDS BY GENDER, ECONOMIC STATUS, AND AGE}

According to the Agrarian Law (Procuraduría Agraria, 2009), only the ejidatarios/as who have a full bundle of rights can decide how to use common lands, who enters the area and what to do with them. Their families and other people living in the ejido can collect resources for daily subsistence, but they cannot participate in decision-making regarding management, exclusion, and alienation. In other words, the law grants access and use rights to most people in the ejido, but it discriminates against landless men and women by limiting their chances to decide on the present and future of common lands.

The use of common lands in El Orito and Benito Juárez include animal herding, stone mining, food and fuel gathering, and community fiestas. The first two (cattle raising, stone mining) are male activities while the last two (food collection and firewood gathering) are conducted by women except for field mice trapping that is performed by poor, landless men. As this section will show, the social construction of men as breadwinners and women as care providers has shaped the traditional use that each gender gives to common lands. Additionally, the privatization of common lands is changing traditional patterns of land use in El Orito, as opposed to Benito Juárez where use patterns remain partially the same.

\section{Cattle Raising}

According to the Agrarian Census [quoted in Linck (1999)], around two thirds of ejido common lands in Mexico are used for animal grazing, typically extensive herding that relies on native pastures. El Orito and Benito Juárez are no exception. In both cases, ejidatarios own cattle and use common lands to graze their herds freely: "I do not know what day, I peeked out around midnight and I saw them [the cows] going uphill” (Rafael Pérez, Peñas de la Virgen, Zacatecas). However, this is slowly changing, more so in El Orito than in Benito Juárez, due to its proximity to the capital city and the presence of MPG in the region. In fact, bovine herds have become increasingly incompatible with El Orito's landscape due to the reduction of adequate areas to keep them. "Urban growth is preventing them [ejidatarios] from doing a lot of things. Animals cannot be kept in the village because they are surrounded by houses. Corrals bring odor problems, flies. Neighbors complain" (Fabiola Sepúlveda, Visiting Judge, Agrarian Attorney's Office, Zacatecas).

Like urban growth, turbine installation also posed a problem for cattle herding in El Orito's common lands. MPG representatives told ejidatarios that changes in land use (from agricultural to industrial) were only on paper, and that it would not affect the traditional use given to El Orito common lands because windmills "were going to be very high, and they are indeed very high" (Mauricio López, ejidatario, El Orito, Zacatecas). However, as soon as the construction of the wind farm began, unexpected problems started to emerge. According 
to Benjamin Jiménez, MPG worker, "there are a lot of ejidatarios who still have cattle and crops... The project had to build a corral... to prevent animals from coming near the turbines." Another MPG employee who refused to be identified pointed out that some cows did fall in the huge holes that were made for the turbines, and that construction work had to be stopped for about 2 weeks due to the damage caused to local vegetation and wildlife. He mentioned biznaga (Echinocactus platyacanthus) and royal eagle (Aquila chrysaetos) among the most affected species. Both are important symbols of Mexico.

The corral remained in the affected area even after the wind farm was completed. Ejidatarios are expected to continue using it in order to prevent possible animal injuries for which the company disclaims any responsibility. Fabiola Sepúlveda even suggested that ejidatarios would have to hire a cowboy to prevent animals from other ejidos from entering the project area. In practical terms, this means that animals can no longer wander freely to fetch their own food, and that their nutrition may have to be complemented with industrial foods. In other words, the wind farm has made ejidatarios dependent on additional resources to sustain their animals. Benjamin Jiménez simply dismissed this as a problem: "ejidatarios have always had their corrals at the limit of their ejidos, and now they will have to move them near roads and turbines." The truth is that a region where animals could wander unsupervised is slowly becoming an industrial venue that needs permanent surveillance.

As opposed to El Orito, Benito Juárez refused to lease its common lands, and people did not report access problems for herds. In Benito Juárez there is a sense of collective land ownership that does not exist in El Orito. One of the activities conducted in the workshops aimed at describing the main ejido areas. Women in Benito Juárez took a considerable amount of time describing to the authors of this paper a common area used to wash cattle. In the following exchange, women suggest that such cattle "belongs to the ejido." What the excerpt shows is that, although individually owned, the ejido of Benito Juárez has kept collective areas for the benefit of the whole, and its authorities have enough legitimacy to charge a moderate amount of money to people willing to use the area to wash their animals:

Question (Q): Who own the cows?

Answer (A): They belong to the ejido, they are washed there, it is their spa.

Q: Do they belong to everybody?

[Women laughing]

$A_{1}$ : It is their spa.

Q: Who takes care of those cows?

$\mathrm{A}_{1}$ : Their owners go there and put them there.

Q: Do people have to pay to wash cows in that spa?

$A_{1}$ : Yes, the ejido charges something.

$\mathrm{A}_{2}$ : Ten pesos per animal (female workshop participants, Benito Juárez, Zacatecas).

\section{Stone Mining}

Stone mining is as important as cattle raising among the men of El Orito and Benito Juárez. Both are considered some of the most traditional occupations that men can have in Zacatecas, and in both ejidos there are identifiable areas where stones can be obtained and stored. However, there are important differences in terms of economic status. Cattle usually belongs to ejidatarios, while stone mining is practiced by poor, landless men. Moreover, there are interesting differences between the two ejidos in terms of the impact of land deals on stone mining, as this section will show.

Some men of El Orito, particularly those living in the rural area of the ejido (Boquillas) were active in stone mining when MPG arrived. These men did not want to rent their lands because they have "stone banks" and "they were exploiting them" However, other ejidatarios "managed to convince them" (Fabiola Sepúlveda, Visiting Judge, Agrarian Attorney’s Office, Zacatecas). Most likely, the ejidatarios who managed to convince them have occupations that do not involve stone mining, an activity considered economically precarious. As noted earlier, the president of the ejido in El Orito (who also was the main advocate of MPG) has a two-floor house and owns the largest and most famous hardware store in town.

Poor, landless men of Benito Juárez make a living as agricultural laborers or as stone miners, depending on the time of the year. The first job pays 180 pesos $^{2}$ a day while in stone mining the pay depends on how skilled the man is. Stones are paid at 25 pesos each, and an experienced man can obtain as much as 300 pesos per day. None of these jobs has medical insurance or any other social benefits. Stone mining is much more dangerous than agricultural labor because it is done manually, with a chisel. Some men can be badly injured and even lose body parts in work accidents. They work for a "big caiman" who sells their product to construction companies. This is how a local NGO worker describes Benito Juárez:

In these villages there are many hills, and people make a living by manufacturing earthenware. They go to the hills with a chisel... and they remove the stones that you can find in sidewalks and stone tables. This is their main occupation (Oscar Maldonado, NGO employee, Zacatecas).

\section{Food and Fuel Collection}

Women participating in both workshops listed various edible resources that could be obtained in their ejidos. Gabriela Lavalle clearly showed the high level of reliance on common lands for survival, particularly among older generations. Water, wild protein and firewood were obtained from them:

Firewood was used for cooking. Firewood was brought from the hills, and tortillas were made at home by women. No one bought tortillas. Water was brought from small wells. Our mothers fed us with field mice broth. Men used to grow food and work in the fields. Now, even beans are sold in cans (Gabriela Lavalle, Benito Juárez, and Zacatecas).

Women in El Orito mentioned with particular nostalgia some fruit trees that can no longer be found in their ejido due to

\footnotetext{
${ }^{2}$ Twenty Mexican pesos per one US dollar.
} 
TABLE 2 | Domestic energy sources in El Orito and Benito Juárez.

\begin{tabular}{lcc}
\hline Energy source & \multicolumn{2}{c}{ Ejido } \\
\cline { 2 - 3 } & \% Benito Juárez $\mathbf{N = 4 0}$ & \% El Orito $\mathbf{N = 4 0}$ \\
\hline $\begin{array}{l}\text { Only gas } \\
\text { Mostly firewood, gas as a }\end{array}$ & 60 & 92.5 \\
second option & 2.5 & 0 \\
$\begin{array}{l}\text { Mainly gas, firewood as a } \\
\text { second option }\end{array}$ & 37.5 & 7.5 \\
Total & 100 & 100 \\
\hline
\end{tabular}

Source: Survey, November 2017.

the arrival of marihuana and urban growth: "there were pear trees, apple trees, plums, white prickly pear fruits, very big, very beautiful. Prickly pear patches were everywhere. But then came the marihuana... and now it is only houses, everything is full of houses" (female workshop participant, El Orito, Zacatecas).

Women in Benito Juárez continue to have access to ejido areas where they can obtain such foods. They mentioned small creeks where they can find edible plants and take small livestock (i.e., goats) to drink water. They also referred to a specific part of the ejido where everyone can collect prickly pear patches. Like the cows' "spa," these common areas "belong to the ejido." "We often go there and no one says anything to us" (female workshop participants, Benito Juárez, Zacatecas).

Another food that can be obtained in the common lands of both ejidos is field mice (Neomata ambigula), an endangered species protected by federal environmental authorities (Márquez, 2002; Secretaría de Medio Ambiente y Recursos Naturales, 2010). Field mice are captured with slingshots and sold at 30-40 pesos each (Mejía, 2017), a price similar to the stones that are also sold by the piece. Like stone mining, field mice trapping is performed by poor, landless men who cannot make a living otherwise, and their consumption is associated with backwardness and poverty. In El Orito and Benito Juárez, field mice consumption has decreased, or so people say; it is difficult to openly admit that field mice instead of beef, pork or chicken is served at your kitchen table. In any case, field mice trappers face an additional problem in El Orito, as opposed to Benito Juárez: the construction of the wind farm has prevented trappers from entering common lands. "Before, rabbit and field mice trappers would go uphill for them, but now, no one can enter the area... many people are watching" (Hugo Robles, ejidatario, El Orito, Zacatecas).

The common lands of Benito Juárez also provide fuel to poor, elderly women. Table 2 shows the existing patterns of domestic use of energy in El Orito and Benito Juárez. In both cases, gas consumption predominates. However, firewood is used as a second option in Benito Juárez when gas is unavailable or women cannot afford it, particularly among landless, poor, elderly women who grew up cooking with firewood.

In fact, elderly women of El Orito and Benito Juárez grew up using both firewood and cow dung for cooking. They continue to use them in spite of the fact that these resources are considered archaic and dirty by younger, more affluent women. María Teresa
Rodríguez defends her use of traditional sources of fuel by referring to young women as "lazy:"

We used to pile cow dung in the kitchen corner and there was no need to go out, we would cook with that. Now women are lazy, they only want gas... Running out of gas does not keep me awake. I go to the hill and bring my firewood, bring my cow dung, I put three or four corn kernels in the cooking pot, and they get cooked (María Teresa Rodríguez, Benito Juárez, Zacatecas).

As opposed to El Orito, where most women already cook with gas, women in Benito Juárez can still find firewood and cow dung in their ejido common lands. The increasing use of gas among younger women has made firewood widely available: "the hills are full of firewood" (María Teresa Rodríguez, Benito Juárez, Zacatecas). As she further explains, there are no regulations regarding who can collect both firewood and cow dung:

Q: You said that both firewood and cow dung can be easily found...

A: Yes, yes.

Q: You said that no one chastises you for bringing some home...

A: No madam.

Q: No one gives you a hard time...

A: If you want, you can come with me, we can cut some firewood and you can take it with you. No one will say anything (María Teresa Rodríguez, Benito Juárez, Zacatecas).

\section{Community Fiestas in El Orito Common Lands}

As soon as the construction of the wind farm started, "no people external to the project" could enter El Orito common lands because they contained private assets (Benjamín Jiménez, MPG employee, Zacatecas). After construction was completed, only the "partners" of the cooperative, namely the 60 ejidatarios, can move freely through the zone. For them to do so they must have a sticker located on a visible part of their vehicle and carry an ID provided by MPG. Partners can be accompanied by "guests," "for example, I take my truck, and I invite Paula or any other family member, and we hang out there. But if she [Paula] goes without me without an ID, they will not let her in" (Mauricio López, ejidatario, El Orito, Zacatecas). Cooperative partners are responsible for the behavior of their guests: "surely there will always be someone who carries a bottle and leaves it there. If something like that happens, they will go after you, and you will get sanctioned for it" (Hernán Lavalle, ejidatario, El Orito, Zacatecas).

These new access restrictions posed a problem to the women who every year organize horseback ridings (cabalgatas) to raise money for two community fiestas (15th of May and 13th of June), a tradition dating back as far as people can remember. A couple of months in advance, women organize around a candidate for queen and they ride to the ejido's common lands to sell food and other products and raise funds for the queen's campaign. However, the MPG contract factually meant that they could no longer access these lands. Cattle was taken care of by building corrals to prevent animal injuries that would entail compensation 
from MPG. Yet, no one thought of the cabalgatas when drafting the contract, mainly because cattle belongs to men and cabalgatas are a female activity from beginning to end. Cabalgatas were temporarily canceled until the 60 cooperative partners reached an agreement with MPG, providing that the norms established by the company "were respected." This made women responsible for the behavior of all people attending their fundraising activities. Security guards are not too kind to them, nor to other people passing through these recently privatized common lands, as stated by a female cyclist who declared in one of the workshops that "security guards treat us like criminals."

\section{CONCLUSIONS}

This paper sought to analyze the gender dynamics of common lands privatization for renewable energy production in two ejidos of Zacatecas, Mexico: El Orito and Benito Juárez. The first agreed to rent its lands to a private company for wind energy generation while the second did not. Previous research on green grabs has shown that women reap few benefits from land deals due to their lack of access to information and royalties; their unequal representation in decision-making bodies; and their reduced bargaining power vis-à-vis government authorities and private investors. The paper adopts a gender and intersectional approach to land grabbing in order to explore how common lands privatization affects women and men.

The contribution of the paper is 2 -fold. First, it shows that even those women who enjoy a full bundle of rights are excluded from decision-making and economic benefits. In theory, ejidatarias should be able to participate in decisions pertaining land management, exclusion and alienation, and they should be eligible for royalties in case of land rentals. In practice, corporations manage to avoid the most important body of collective decision-making in the ejido by negotiating individually with a few men who, in turn, systematically refuse to protect ejidatarias' right to voice their concerns, vote in assemblies and receive economic benefits from land rentals. Benefits from land rentals are concentrated on a handful of men, thus increasing previously existing disparities based on gender and economic status.

Second, the impacts of land grabs vary according to gender, economic status and age. In El Orito, green grabs exacerbated differences between ejidatarios willing to rent their lands and ejidatarios refusing to do so; between male landholders and landless, poor men who work as stone miners; between ejidatarios who are receiving royalties and those who are not; between ejidatarios receiving royalties and ejidatarias being silenced by their sons. The most privileged group of people are the few ejidatarios who privatized and rented their common lands and still have arable lands. Some of them owh other businesses to make a living.

Women in El Orito do not own cattle, nor do they practice stone mining. However, they have used common lands for generations to obtain food and fuel and organize community fiestas. Some women still remember the resources that can no longer be found in their ejido due to urban growth. In addition, their community fiestas were affected when the wind farm was installed because no one thought of consulting them. As opposed to men, some of whom managed to benefit from land deals, most women in El Orito were negatively affected by them.

Benito Juárez served as a good point of comparison because its common lands were not privatized, and people continue to use them in traditional ways. However, people in Benito Juárez also hold different bundles of rights based on gender, economic status and age. Landless, poor men depend the most on common lands for survival, because they work as stone miners during some months of the year. Accordingly, landless, poor, elderly women gather fuel for cooking purposes because they cannot afford gas. If green grabs were to expand in ejidos like Benito Juárez, special attention must be paid to the groups that may suffer the most. In Zacatecas these groups include landless, poor men who practice stone mining, and landless, poor, elderly women who gather fuel from common lands.

The paper concludes that, in spite of the government's attempt at fragmenting and privatizing ejido lands, the Agrarian Law still recognizes ejidos as a group of peasants with a common history, and the ejido assembly still has the power to deny the entry of corporations into their territories. In El Orito, the fragmentation of common lands together with arable lands facilitated the installation of the wind farm. By contrast, ejidatarios in Benito Juárez only agreed to receive titles for the arable lands that they were already working individually, and they decided to keep their common lands intact, under collective management. This difference explains the success of the company in El Orito as opposed to Benito Juárez, and it also shows the importance of strengthening ejidos' ability to defend their common lands in Zacatecas and throughout the country.

Women are not participating in the process in any way, in spite of the fact that some have the full bundle of rights granted by law, and the rest are important users of common lands for many different purposes. Women are invisible to the eyes of government officials, company representatives and ejido members. They received very little information on the wind farm and have no opinion on the process, its impacts, and benefits. Their roles as community leaders were invisible to project implementers, as the annual fiestas undertaken by them had to be suspended until a handful of men sat at the table to reconsider access restrictions to El Orito common lands. These disparities need to be redressed as soon as possible to further strengthen ejidos' ability to counteract privatization reforms, with women as central players of the process.

\section{DATA AVAILABILITY STATEMENT}

The raw data supporting the conclusions of this article will be made available by the authors, without undue reservation.

\section{ETHICS STATEMENT}

Ethical review and approval was not required for the study on human participants in accordance with the local legislation 
and institutional requirements. Written informed consent for participation was not required for this study in accordance with the national legislation and the institutional requirements.

\section{AUTHOR CONTRIBUTIONS}

DS-C processed the quantitative information. VV-G processed the qualitative information. Research was conducted by both authors. The paper was written by both of them.

\section{REFERENCES}

Agarwal, B. (1994). Gender, resistance and land-interlinked struggles over resources and meanings in South Asia. J. Peasant Stud. 22, 82-125. doi: 10.1080/03066159408438567

Agarwal, B. (2003). Gender and land rights revisited: exploring new prospects via the state, family and market. J. Agrarian Change 3, 184-224. doi: $10.1111 / 1471-0366.00054$

Almeida, E. (2012a). Ejidatarias, posesionarias, avecindadas. Mujeres frente a sus derechos de propiedad en tierras ejidales de México. Revista de Estudios Agrarios 18, 13-57. Available online at: https://www.pa.gob.mx/publica/rev_52/ analisis/ejidatarias_posesionarias_avecindadas.pdf (accessed January 17, 2021).

Almeida, E. (2012b). Herencia y donación. Prácticas intrafamiliares de transmisión de la tierra. El caso de un ejido veracruzano. Cuicuilco 54, 55-79. Available online at: http://www.redalyc.org/articulo.oa?id=35126359004 (accessed January 17, 2021).

Andrade Sáenz, N. (2009). La Adopción del dominio pleno como causal de la extinción de los ejidos y comunidades en México. (Bachelor of Arts in Law thesis). Universidad Michoacana de San Nicolás Hidalgo, Michoacan, Mexico.

Avilés Hernández, O. V. (2013). Conflictos territoriales y perspectivas de desarrollo de la energía eólica en el istmo de Tehuantepec. Revista Mexicana de Opinión Pública 9, 67-79. doi: 10.22201/fcpys.24484911e.2010.9.41818

Banana, A. Y., Bukenya, M., Arinaitwe, E., Birabwa, B., and Sekindi, S. (2012). Gender, Tenure and Community Forests in Uganda. Workin Paper \# 87. Bogor. Available online at: https://www.cifor.org/publications/pdf_files/ WPapers/WP87CIFOR.pdf (accessed January 10, 2021).

Behrman, J., Meinzen-Dick, R., and Quisumbing, A. (2012). The gender implications of large-scale land deals. J. Peasant Stud. 39, 49-79. doi: 10.1080/03066150.2011.652621

Borras, S. M., and Franco, J. C. (2013). Global land grabbing and political reactions "from below." Third World Quart. 34, 1723-1747. doi: 10.1080/01436597.2013.843845

Brown, J. (2004). Ejidos and comunidades in Oaxaca, Mexico: impact of the 1992 reforms. RDI Reports on Foreign Aid and Development. Seattle, WA: Rural Development Institute.

Buechler, S., Vázquez-García, V., Martínez, K., and Sosa-Capistrán, D. M. (2020). Patriarchy and electric power? A feminist political ecology of solar energy use in Mexico and the United States. Energy Res. Soc. Sci. 70, 1-10. doi: $10.1016 /$ j.erss.2020.101743

Centro de Estudios para el Desarrollo Rural Sustentable y la Soberanía Alimentaria (2015). La propiedad social rural y su perfil productivo. Ciudad de México: CEDRSSA, Cámara de Diputados.

Comisión Nacional para el Diálogo con los Pueblos Indígenas de México (2013). La energía eólica en México. Una perspectiva social sobre el valor de la tierra. Comisión Nacional para el Diálogo con los Pueblos Indígenas de México. Ciudad de México: CNDPI.

Costa Leonardo, N., and Velasco Ocampo, M. G. (2012). Perfil de la mujer rural en México. Ciudad de México: Secretaría de la Reforma Agraria.

Crenshaw, K. (1989). Demarginalizing the intersection of race and sex: a black feminist critique of antidiscrimination doctrine, feminist theory and antiracist politics. Univ. Chicago Legal Forum 1, 139-167.

Daley, E. (2011). Gendered impacts of commercial pressures on land. Commercial Pressures on Land Initiative. Rome: International Land Coalition.

\section{FUNDING}

Research was supported by these two projects: Género y pobreza energética en Oaxaca y Zacatecas, funded by the Programa de Investigación en Cambio Climático (PINCC), Universidad Nacional Autónoma de México; and Towards improved synergies: Women, natural resource based livelihoods and renewable energy in Arizona and Zacatecas, funded by the Consortium for Arizona-Mexico Arid Environments (CAZMEX).

Daley, E., and Pallas, S. (2014). Women and Land Deals in Africa and Asia: weighing the Implications and Changing the Game. Femin. Econ. 20, 178-201. doi: 10.1080/13545701.2013.860232

Deere, C. D., and León, M. (2005). La brecha de género en la propiedad de la tierra en América Latina. Estudios Sociológicos 23, 397-439. doi: 10.24201/es.2005v23n68.367

Fonjong, L., Sama-Lang, I., Fombe, L., and Abonge, C. (2016). Land governance and women's rights in large-scale land acquisitions in Cameroon. Dev. Pract. 26, 420-430. doi: 10.1080/09614524.2016.1162285

Fraser, N. (2008). La justicia social en la era de la política de identidad: redistribución, reconocimiento y participación. Revista de Trabajo 4, 83-99. Available online at: http://trabajo.gob.ar/downloads/igualdad/08ago-dic_ fraser.pdf (accessed April 19, 2021).

García-Torres, M. (2018). El IBEX 35 en guerra contra la vida. Transnacionales españolas y conflictos socioecológicos en América Latina. Madrid: Ecologistas en Acción.

Gay-Antaki, M. (2016). "Now we have equality:" a feminist political ecology analysis of carbon markets in Oaxaca, Mexico. J. Latin Am. Geogr. 15, 49-66. doi: 10.1353/lag.2016.0030

Gobierno de Zacatecas (2017). En Zacatecas hay condiciones para generar energía limpia para las empresas que busquen instalarse: Tello. Noticias, Estado de Zacatecas. Available online at: https://www.zacatecas.gob.mx (accessed April $19,2021)$.

GRAIN (2014). Reformas energéticas. Despojo y defensa de la propiedad social de la tierra. Available online at: https://grain.org/es/article/5118-reformasenergeticas-despojo- $y$-defensa-de-la-propiedad-social-de-la-tierra\#:\$ $\mid$ sim\$: text=Reformas\%20energ\%C3\%A9ticas\%20despojo\%20y\%20defensa\%20de $\% 201$ a\%20propiedad\%20social\%20de\%20la\%20tierra-by\%20CECCAM $\% 20$ \%7C\%20GRAIN\&text\$=\$El\%20Estado\%20mexicano\%20ha\%20decidido,la \%20inf (accessed December 29, 2020).

Gray, L., and Kevane, M. (1999). Diminished access, diverted exclusion: women and land tenure in Sub-Saharan Africa. Afri. Stud. Rev. 42, 15-39. doi: $10.2307 / 525363$

Hernández Artigas, A. (2018). Opresión e interseccionalidad. Revista Internacional de Eticas Aplicadas 26, 275-284. Available online at: https://ialnet.unirioja.es/ servlet/articulo? codigo $=6278551$ (accessed May 20, 2021).

Hernández Navarro, L. (2016). "Reforma al campo y leyes energéticas," in La nueva servidumbre agraria y la resistencia indígena y campesina, eds L. Hernández Navarro and A. de I. Rubio (Ciudad de México: Centro de Estudios para el Cambio en el Campo Mexicano), 1-11.

Hoang Yen, M., Mwamgi, E., and Wan, M. (2012). Gender analysis in forestry research: looking back and thinking ahead. Gender analysis in forestry research: looking back and thinking ahead. Bogor: CIFOR.

Instituto Nacional de Estadistica Geografía e Informatica (2020). Censo de Población y Vivienda 2020. Available online at: https://www.inegi.org.mx (accessed May 12, 2021).

Juárez-Hernández, S., and León, G. (2014). Wind energy in the isthmus of Tehuantepec: development, actors and social opposition. Problemas del Desarrollo 45, 139-162. doi: 10.1016/S0301-7036(14) 70879-X

Larson, A. M., Barry, D., and Ram Dahal, G. (2010). Forest tenure reform: new resource rights for forest-based communities. Int. Forestry Rev. 10, 77-90. doi: 10.4103/0972-4923.97478 
León, I. (2017). Tras siete años, Power Group inaugurará parque eólico en Zacatecas. El Financiero. Available online at: https://www.elfinanciero.com.mx/ empresas/tras-anos-power-group-inaugurara-parque-eolico-en-zacatecas/\#: \$ $\backslash$ sim \$:text=El\%20'Parque\%20E\%C3\%B3lico\%20La\%20Bufa,45\%20millones \%20de\%20pesos\%20anualmente.\&text\$ $\$$ Zacatecas (accessed March 7, 2021).

Linck, T. (1999). Tierras de uso común, regímenes de tenencia y transición agraria en México. Estudios Agrarios 12, 119-151. Available online at: http://www.pa. gob.mx/publica/rev_12/Thierry.pdf (accessed January 10, 2021).

Márquez, M. (2002). Características reproductivas de la rata magueyera (Neomata albigula) en cautiverio. Acta Zoológica Mexicana 86, 139-144. Available online at: http://www.scielo.org.mx/scielo.php?script=sci_abstract\& pid=S0065-17372002000200008\&lng=es\&nrm=iso (accessed May 12, 2021).

Martínez Mendoza, E., Rivas Tovar, L. A., and Vera Martínez, P. S. (2018). El sector eólico en México y España. Perfiles Latinoamericanos 27, 1-21. doi: 10.18504/pl2753-002-2019

Mejía, I. (2017) ¿Comerías caldo de rata de campo? El Universal. Available online at: https://www.eluniversal.com.mx/estados/comerias-caldo-de-ratade-campo (accessed November 27, 2017).

México Power Group (MPG) (2014). México Power Group. Available online at: https://www.thewindpower.net/developer_es_4367_mexico-power-group. php (accessed January 10, 2021).

Mollett, S., and Faria, C. (2013). Messing with gender in feminist political ecology. Geoforum 45, 116-125. doi: 10.1016/j.geoforum.2012.10.009

Mukasa, C., Tibazalika, A., Mango, A., and Muloki, H. N. (2012). Gender and forestry in Uganda: Policy, legal and institutional frameworks. Working Paper 89 53, 1-51. Available online at: http://www.cabdirect.org/abstracts/ 20143006941.html;ssessionid $\$=\$ 401063$ D0AB8BE9F8C3019A17A602583E (accessed December 28, 2020)

Olivera, B. (2019). "La participación de las mujeres rurales en la defensa del territorio en México", in Caminos desde abajo. Organización social y usos del derecho en la defensa del territorio en México, eds E. del Pozo Martínez and J. C. Martínez (Ciudad de México: Fundar, Centro de Análisis e Investigación, A. C. and Gedisa Editorial), 247-79.

Ossome, L. (2014). Can the law secure women's rights to land in africa? revisiting tensions between culture and land commercialization. Femin. Econ. 20, 155-177. doi: 10.1080/13545701.2013.876506

Procuraduría Agraria (PA) (2009). Glosario de términos jurídico-agrarios. Ciudad de México: Procuraduría Agraria.

Registro Agrario Nacional (1998). Catálogo de núcleos agrarios de la propiedad social. Available online at: https://datos.ran.gob.mx/conjuntoDatosPublico.php (accessed January 28, 2021).

Ruiz Meza, L. E. (2006). Género, grupos domésticos y derechos de propiedad21 sobre la tierra. El Cotidiano 21, 7-19. Available online at: https://www.redalyc. org/articulo.oa?id=32513902 (accessed May 12, 2021).

Ruiz Meza, L. E. (2012). Relaciones de género y mercados de derechos de agua y tierra en Chiapas. Región y Sociedad 24, 55-90. doi: 10.22198/rys.2012.53.a162

Sales Gelabert, T. (2017). Repensando la interseccionalidad desde la teoría feminista. Agora Papeles de Filosofía 36, 229-256. doi: 10.15304/ag.36.2.3711

Schlager, E., and Ostrom, E. (1992). Property-rights regimes and natural resources: a conceptual analisis. Land Econ. 68, 249-262. doi: 10.2307/3146375

Scoones, I., Hall, R., Borras, S. M., White, B., and Wolford, W. (2013). The politics of evidence: methodologies for understanding the global land rush. J. Peasant Stud. 2013:801341. doi: 10.1080/03066150.2013.801341

Secretaría de Agricultura y Desarrollo Rural (2018). Principales cultuvos en el estado y lugar que ocupa en el contexto nacional (2017). Available online at: https://coepla.zacatecas.gob.mx/wp-content/uploads/2018/04/Cierre Agricola2017_Zac.pdf (accessed January 28, 2021).
Secretaría de Medio Ambiente y Recursos Naturales (2010). Norma Oficial Mexicana NOM-059-SEMARNAT-2010, Lista de especies en riesgo. Available online at: https://www.dof.gob.mx/normasOficiales/4254/semarnat/semarnat. htm (accessed April 20, 2021).

Tejada, L., and Rist, S. (2019). "El boom del bioetanol y (re)concentración de la tierra en la costa norte peruana: luchas agrarias en un contexto neoliberal", in Naturaleza y neoliberalismo en América Latina, eds L. Durand, A. Nygren and De la Vega-Leinert, A.C. Cuernavaca (Morelos: Centro Regional de Investigaciones Multidisciplinarias UNAM), 215-248.

Torres Fragoso, J., and Luna Espinoza, I. (2018). Políticas públicas para el desarrollo regional el caso de la industria eólica en el Istmo de Tehuantepec, Oaxaca, México. Ciencia Administrativa 1, 125-143. Available online at: http://www.scielo.org.mx/scielo.php?script=sci_arttext\&pid=S030170362014000300007 (accessed April 20, 2021).

Trench, T., and Amico, A. L. (2019). "Es REDD+ un instrumento de neoliberalización? Experiencias desde Chiapas y Yucatán en el sur de México", in Naturaleza y neoliberalismo en América Latina, eds L. Durand, A. Nygren, and De la Vega-Leinert, A. C. Cuernavaca (Morelos: Centro Regional de Investigaciones Multidisciplinarias UNAM), 81-126.

Vázquez-García, V. (2007). La recolección de plantas y la construcción genérica del espacio. Un estudio de veracruz, México. Ra Ximhai 3, 805-825. doi: 10.35197/rx.03.03.2007.17.vv

Vázquez-García, V. (2016). "Género y derechos agrarios en México. Reflexiones a más de dos décadas de la reforma de 1992, in Transformaciones ambientales e igualdad de género en América Latina, eds M. Velázquez, V. Vázquez García, A. De Luca, and Sosa Capistrán, D. M. Cuernavaca (Morelos: Centro Regional de Investigaciones Multidisciplinarias UNAM), 173-196.

Vázquez-García, V., and Ortega Ortega, T. (2017). Gender, local governance and non timber forest products. The use and management of Satureja macrostema in Oaxaca’s central valleys, Mexico. Women's Stud. Int. Forum 65:3. doi: 10.1016/j.wsif.2016.08.003

Vázquez-García, V., and Sosa-Capistrán, D. M. (2020). Seguridad energética e interseccionalidad de género en Zacatecas, México. Sociedad Ambiente 7, 131-154. doi: 10.31840/sya.v0i21.2043

White, B., and White, J. (2011). "The gendered politics of dispossession: oil palm expansion in a Dayak Hibun community in West Kalimantan, Indonesia," in International Conference on Global Land Grabbing 6-8 April 2011. Land Deal Politics Initiative. Available online at: https://www.oicrf.org/documents/40950/ 43224/The \$+\$gendered\$+\$politics\$+\$of\$+\$dispossession\$+\$oil\$+\$palm\$+ \$expansion\$+\$in $\$+\$ a+\$$ Dayak $\$+\$$ Hibun $\$+\$$ community $\$+\$ i n \$+\$$ West $\$+$ \$Kalimantan\$+\$ndonesia.pdf/307c8a50-5143-4b24-a6e4-6399f21b42aa?t= 1510224581067 (accessed January 20, 2021).

Zapata, E., Gutiérrez, B. M., and Flores, A. (2006). Caminar por los tepetates. La visión de las mujeres de Hueyotlipan, Tlaxcala, México. Texcoco: Colegio de Postgraduados.

Conflict of Interest: The authors declare that the research was conducted in the absence of any commercial or financial relationships that could be construed as a potential conflict of interest.

Copyright (๑) 2021 Vázquez-García and Sosa-Capistrán. This is an open-access article distributed under the terms of the Creative Commons Attribution License (CC BY). The use, distribution or reproduction in other forums is permitted, provided the original author(s) and the copyright owner(s) are credited and that the original publication in this journal is cited, in accordance with accepted academic practice. No use, distribution or reproduction is permitted which does not comply with these terms. 